\title{
Presence of Aflatoxin Carcinogens in Fresh and Mature Cheeses
}

\section{Rojas-Marín V, Carvajal-Moreno $\mathbf{M}^{*}$, González-Villaseñor MC, García-Hernández EA and González-Mendoza A}

Institute of Biology, National Autonomous University of Mexico (UNAM), University City, Delegación Coyoacán, 04510, CdMx, México

\begin{abstract}
Cheese has a high nutritional value so it is considered an essential food in the human diet. This review considered 27 countries with 59 different kinds of cheeses highly consumed per person, with France and the USA as the largest consumers with $26 \mathrm{~kg}$ and $15 \mathrm{~kg}$ per inhabitant per year, respectively. Mexico has a consumption of $2.1 \mathrm{~kg}$ per capita in a year. The presence of aflatoxins in cheeses represents a risk for human health because the International Agency for the Research of Cancer (IARC) classified them as Grade I, meaning that they are proven carcinogens to humans. Almost all of the countries reported aflatoxin $M_{1}$ in cheese, and only Mexico analyzed eight different aflatoxins and hydroxylates in this dairy product. It is also important to analyze the hydroxylate metabolites of aflatoxins because they are also carcinogenic and they increase the amount of ingested carcinogens in cheese samples, allowing us to obtain the real ingested dose.
\end{abstract}

Keywords: Aflatoxins; Cheeses; Food carcinogens; Human cancer

\section{Introduction}

Aflatoxins are undesirable mycotoxins that contaminate cheese directly through rennet or contaminate milk indirectly from oilseeds or cereals with the fungi Aspergillus flavus or A. parasiticus in animal feed. Cheese is produced by the addition of rennet or other enzymes to curdle the milk of certain mammals, such as cattle, sheep and goats, in the presence of lactic acid produced by spiked or natural microorganisms in milk; part of the humidity is eliminated when the curd is cut [1]. An accepted definition of cheese is "A fresh or refined product, solid or semisolid obtained by the coagulation of the entire milk, skimmed or partially skimmed due to the action of rennet..." [2]. Milk can be raw or pasteurized, and for the formation of cheese, two processes are required: curdling and acidification of the milk. Rennet is an aspartic protease enzyme extracted from the abomasum that is in the fourth stomach of bovines, and it acts by separating casein from its liquid phase, water, milk serum and carbohydrates. It is also produced in human babies to curdle the mother's milk [3]. Acidification to $\mathrm{pH} 4.5$ precipitates the insoluble protein via the action of bacteria or the addition of vinegar or lemon juice [4]. Bacteria convert milk carbohydrates into lactic acid, which plays an important role in the texture and organoleptic properties of cheeses [5]. The different flavors and textures of the cheeses depend on the kind of milk employed, the additives, the curdle time and the modification of proteins and fats by the different microorganisms employed, such as the lactic acid and propionic bacteria [6]. Additionally, some fungal strains are utilized, such as Penicillium roqueforti for making blue cheese or Roquefort and Penicillium camemberti for making Camembert and Brie cheeses [7]. Cheese is one of the most nutritive foods for humans as a source of calories; proteins; carbohydrates; saturated (AGS), unsaturated (AGM) and poly-unsaturated (AGP) fats; cholesterol, vitamin D; calcium; and sodium [3].

\section{Production of Milk and Cheese in Mexico and Worldwide}

The bovine milk production worldwide in 2016 was 488,812,000 tons, of which $189,080,000$ tons (39\%) was produced in the European Union and East Europe. The American continent was ranked in second place with $155,637,000$ tons $(32 \%)$. Asia produced $113,340,000$ tons (23\%), and Oceania registered a production of $30,755,000$ tons $(6 \%)$ [8]. In 2013, the European Union cheese production was $645,776,815$ tons, Saudi Arabia produced 231,341,350 tons, New Zealand produced 269,306,317 tons, the United States of America produced 170,262,254 tons, Egypt produced 160,111,100 tons, and Australia produced $163,163,170$ tons [8].

The USA was ranked first in bovine milk production in 2016, with $62 \%$, followed by Brazil, which produced $17 \%$ and Mexico was in third place with $8 \%$. Argentina and Canada produced $6 \%$ and $7 \%$ of bovine milk, respectively [8]. The total cheese production in the world is 18 million tons, with the USA generating $30 \%$ of the world's production, followed by Germany with $13 \%$, France with $12 \%$ and Italy with $7.5 \%$. The remaining production is generated by The Netherlands, Poland, Brazil, Egypt and Argentina, among others. Mexico produced 282,000 tons of cheese in 2015, and it exported 4,112 tons and imported 116,117 tons [9].

\section{Aflatoxins}

Aflatoxins (AF) are a group of toxic secondary metabolites produced mainly by the fungi Aspergillus flavus, A. parasiticus and A. nomius [10]. These species are ubiquitous in nature, and they can contaminate dry fruits, oilseeds, cereals and spices. These contaminants can affect plants in the field, crops, transportation or warehouses [11].

The main entrance of AFs in mammals is through the ingestion of contaminated foods and feeds, with the liver as the main affected target [12]. AFs damage animals and humans and are considered the most potent natural mutagens and carcinogens that can link to DNA and be stored for years [13]. Aflatoxin $\mathrm{B}_{1}\left(\mathrm{AFB}_{1}\right)$ is classified as a proven Group I carcinogen for humans [14]. Aflatoxin $M_{1}$ is possibly carcinogenic to humans and was classified as a Group 2B carcinogen by the IARC (1997) [15]. The acute symptoms related to AF consumption are vomiting, hemorrhaging, diarrhea and death. The chronic symptoms

*Corresponding author: Dr. Magda Carvajal-Moreno, Department of Botany, Institute of Biology, National Autonomous University of Mexico (UNAM), University City, Delegation Coyoacán, 04510, CdMx, Mexico, Tel: +5255 2523 8297; Fax: + 52555550 1760; E-mail: magdac@ib.unam.mx

Received March 13, 2018; Accepted March 23, 2018; Published March 30, 2018

Citation: Rojas-Marín V, Carvajal-Moreno M, González-Villaseñor MC, GarcíaHernández EA, González-Mendoza A (2018) Presence of Aflatoxin Carcinogens in Fresh and Mature Cheeses. Pharm Anal Acta 9: 581. doi: 10.4172/21532435.1000581

Copyright: (c) 2018 Rojas-Marín V, et al. This is an open-access article distributed under the terms of the Creative Commons Attribution License, which permits unrestricted use, distribution, and reproduction in any medium, provided the original author and source are credited. 
Citation: Rojas-Marín V, Carvajal-Moreno M, González-Villaseñor MC, García-Hernández EA, González-Mendoza A (2018) Presence of Aflatoxin Carcinogens in Fresh and Mature Cheeses. Pharm Anal Acta 9: 581. doi: 10.4172/2153-2435.1000581

Page 2 of 6

include immunosuppression, fetal malformations, cirrhosis, hepatitis, and several cancers such as hepatocellular carcinoma and colorectal, cervical, breast, pancreatic and lung cancers [16,17].

\section{Consumption and Excretion of AFs in Cattle}

In the case of domestic animals, such as bovines, goats and sheep, the feed ingestion of $\mathrm{AFB}_{1}$ and aflatoxin $\mathrm{B}_{2}\left(\mathrm{AFB}_{2}\right) \mathrm{AFs}$ is due to the ingestion of balanced feeds produced with contaminated cereals and poultry litter [18]. $\mathrm{AFB}_{1}$ and $\mathrm{AFB}_{2}$ are not very soluble in water, and thus, in order to eliminate them from the animal, the liver adds a $\mathrm{OH}$ molecule to transforms these species into the hydroxylates aflatoxin $M_{1}$ $\left(\mathrm{AFM}_{1}\right)$, aflatoxin $\mathrm{M}_{2}\left(\mathrm{AFM}_{2}\right)$, aflatoxin $\mathrm{P}_{1}\left(\mathrm{AFP}_{1}\right)$ and aflatoxicol $(\mathrm{AFL})$, which are very soluble in water and can be eliminated from the body in urine, maternal milk and litter. AFL is interconvertible with $\mathrm{AFB}_{1}$ and remains stored, and although it is less carcinogenic than $\mathrm{AFB}_{1}$, it is still very carcinogenic and cannot be considered a decontamination product [19]. $\mathrm{AFM}_{1}, \mathrm{AFM}_{2}, \mathrm{AFP}_{1}$ and $\mathrm{AFL}$ are excreted into the milk of lactating cows in 1 to $3 \%$ of the original $\mathrm{AFB}_{1}$ concentration consumed in the diet. Therefore, all of these AFs and their hydroxylated metabolites s with
AFL are detected in the milk of cattle, goats and sheep, and from there, they are incorporated into cheeses highly consumed by humans [20].

\section{Aflatoxins in Milk and Cheeses in Mexico and Worldwide}

AFs have been identified in raw and pasteurized milk in Brazil, Turkey, Kuwait, Italy, Serbia [21-23] and Australia [24]. There are reports of $\mathrm{AFs}\left(\mathrm{AFB}_{1}, \mathrm{AFM}_{1}\right.$ and $\left.\mathrm{AFL}\right)$ in $580 \mathrm{~L}$ of Mexican milk, where $13 \%$ of pasteurized and $8 \%$ of ultrapasteurized milk with different amounts of fat contained AFL $\left(>0.05 \mu \mathrm{g} \mathrm{L} \mathrm{L}^{-1}\right)[25,26]$ and AFL was also found in artisanal Oaxaca cheese in Veracruz, Mexico [27,28]. There were only traces of $\mathrm{AFB}_{1}(0 \mathrm{a} 0.4 \mu \mathrm{g} / \mathrm{L})$, and the amount of fat was not significant.

The detection of $\mathrm{AFM}_{1}$ in the State of Hidalgo, Mexico, was reported in 2007 with a concentration from 167 to $332 \mu \mathrm{g} \mathrm{L}^{-1}$ [29]. Other reports from the central high plateau of Mexico in 2008 found 59\% (26/44) of $\mathrm{AFM}_{1}$ contamination $\left(>0.05 \mu \mathrm{g} \mathrm{kg}^{-1}\right)$, which is the highest tolerable level in the European Community [30]. The detection of $\mathrm{AFM}_{1}$ in $100 \%$ $(50 / 50)$ of the milk samples was obtained from Guadalajara, Jalisco,

\begin{tabular}{|c|c|c|c|c|c|c|}
\hline $\mathbf{N}^{\circ}$ & Country & Cheese type & $\begin{array}{c}\text { +/total samples or } \\
\text { sample } \%\end{array}$ & Aflatoxin & $\begin{array}{c}\text { Concentration } \\
\left(\mu \mathrm{kg}^{-1}\right)\end{array}$ & Source \\
\hline 1 & Australia & - & - & \multirow{35}{*}{ M1 } & - & [24] \\
\hline 2 & \multirow{5}{*}{ Brazil } & Prato, Parmesan & $0 / 36$ & & ND & [33] \\
\hline 3 & & \multirow{2}{*}{ Minas cheese } & $48 / 58$ & & 10 to 304 & [34] \\
\hline 4 & & & $13 / 48$ & & 0.04 A 0.31 & [35] \\
\hline 5 & & Artisanal & $3.2 \%$ & & & [36] \\
\hline 6 & & Parmesan & $18 / 30$ & & 0.16 & [37] \\
\hline 7 & Czechoslovakia & Edam-type & $29,20 \%$ & & $5-66$ & [38] \\
\hline 8 & China & \multirow{3}{*}{ Artisanal white fresh cheese } & $4 / 4$ & & & [39] \\
\hline 9 & Colombia & & $37 / 37$ & & 5 to 351 & [40] \\
\hline 10 & Costa Rica & & $10 / 70$ & & 31 to 276 & {$[8,41]$} \\
\hline 11 & Denmark, & Blue and white mould & $0 / 10$ & & ND & [42] \\
\hline 12 & Ecuador & $\begin{array}{l}\text { Artisanal white } \\
\text { fresh cheese }\end{array}$ & $7 / 33$ & & 0.04 to 0.83 & [43] \\
\hline 13 & Egypt & Kareish \& Damietta & $20 / 50$ & & 1.95 to 14.75 & {$[44]$} \\
\hline 14 & Finland & \multirow{3}{*}{ Blue and white mould } & $0 / 10$ & & ND & \multirow{3}{*}[42]{} \\
\hline 15 & France & & $0 / 10$ & & ND & \\
\hline 16 & Germany, & & $0 / 10$ & & ND & \\
\hline 17 & Greece & Feta \& Teleme & $0 / 127$ & & ND & [45] \\
\hline 18 & \multirow{9}{*}{ Iran } & \multirow{9}{*}{ White cheese } & $8,87 \%$ & & $\mathrm{NRb}$ & [46] \\
\hline 19 & & & $195 / 360$ & & 50.5 a 309 & [47] \\
\hline 20 & & & $52 / 100$ & & 50.2 a 424 & [48] \\
\hline 21 & & & $188 / 545$ & & - & \multirow{2}{*}[49]{} \\
\hline 22 & & & $26 / 40$ & & 52.5 to 272 & \\
\hline 23 & & & $35 / 39$ & & 0.004 a 0.023 & [50] \\
\hline 24 & & & $73 / 75$ & & - & \multirow{2}{*}[51]{} \\
\hline 25 & & & $56 / 75$ & & 0.12 & \\
\hline 26 & & & $161 / 210$ & & 52.1 a 785.4 & [10] \\
\hline 27 & \multirow{5}{*}{ Italy } & \multirow{2}{*}{ Cheese } & $6,83 \%$ & & $50-400$ & [52] \\
\hline 28 & & & $50,8 \%$ & & $50-100$ & [53] \\
\hline 29 & & \multirow{3}{*}{ Artisanal fresh } & $44 / 265$ & & 50 to 250 & {$[54]$} \\
\hline 30 & & & $11 / 24$ & & 5.0 to 20 & [55] \\
\hline 31 & & & $12 / 24$ & & 0.05 & {$[56]$} \\
\hline 32 & \multirow{2}{*}{ Japan } & \multirow{2}{*}{ Cheese } & $303,14 \%$ & & $200-1200$ & [57] \\
\hline 33 & & & $0 / 41$ & & $\mathrm{ND}$ a & {$[58]$} \\
\hline 34 & Korea & \multirow{2}{*}{ Artisanal fresh } & $83 / 108$ & & 0.02 to 0.14 & [59] \\
\hline 35 & Kuwait & & $32 / 40$ & & 23.8 to 452 & {$[60]$} \\
\hline
\end{tabular}


Citation: Rojas-Marín V, Carvajal-Moreno M, González-Villaseñor MC, García-Hernández EA, González-Mendoza A (2018) Presence of Aflatoxin Carcinogens in Fresh and Mature Cheeses. Pharm Anal Acta 9: 581. doi: 10.4172/2153-2435.1000581

Page 3 of 6

\begin{tabular}{|c|c|c|c|c|c|c|}
\hline 36 & \multirow{4}{*}{ Mexico } & \multirow{2}{*}{ Oaxaca fresh } & $19 / 30$ & M1, M2 & 0.01 to 3.4 & [28] \\
\hline 37 & & & $30 / 30$ & $\mathrm{~B}_{1}, \mathrm{~B}_{2}, \mathrm{G}_{1}, \mathrm{G}_{2}, \mathrm{M}_{1}, \mathrm{M}_{2}, \mathrm{P}_{1}, \mathrm{AFL}$ & 0.1 to 19.1 & {$[27]$} \\
\hline 38 & & Goat cheese & $3 / 20$ & \multirow{36}{*}{ M1 } & 0 to 0.23 & [61] \\
\hline 39 & & Fresh goat cheese & $3 / 20$ & & 0.23 & [31] \\
\hline 40 & Netherlands & Mature ripened & $-/ 88$ & & & [62] \\
\hline 41 & North Africa & White soft & $20,75 \%$ & & $110-520$ & [63] \\
\hline 42 & Portugal & Mature cheese & $8 / 128$ & & $>0.05$ & [64] \\
\hline 43 & Rumania & Ripened mature & 9/50 & & $<50$ & [65] \\
\hline 44 & \multirow{4}{*}{ Spain } & Cheese & $35,44 \%$ & & $20-200$ & [66] \\
\hline 45 & & Manchego & $50 \%$ & & - & [67] \\
\hline 46 & & Artisanal fresh cheese & $0 / 72$ & & 0 & [68] \\
\hline 47 & & Manchego, requesón & $80 / 82$ & & & [69] \\
\hline 48 & Slovenia & Raw artisanal cheese & $10 \%$ & & $>50 \mathrm{ng} / \mathrm{kg}$ & [70] \\
\hline 49 & \multirow{25}{*}{ Turkey } & Lor & $6,33 \%$ & & $13-19$ & \multirow{8}{*}{72} \\
\hline 50 & & Civil & $9,44 \%$ & & $12-18$ & \\
\hline 51 & & Tulum & $11,63 \%$ & & $11-202$ & \\
\hline 52 & & Kashar & $14,42 \%$ & & $7-68$ & \\
\hline 53 & & White & $23,39 \%$ & & $11-106$ & \\
\hline 54 & & Tulum, white & $100,82 \%$ & & $51->800$ & \\
\hline \multirow{2}{*}{56} & & \multirow{3}{*}{ Cream } & $49,89 \%$ & & 800 & \\
\hline & & & $100,79 \%$ & & $51-650$ & \\
\hline 57 & & & $200,4 \%$ & & $100-700$ & \multirow{3}{*}{73} \\
\hline 58 & & White & $200,5 \%$ & & $100-600$ & \\
\hline \multirow{3}{*}{$\begin{array}{c}59 \\
60 \\
61\end{array}$} & & \multirow{2}{*}{ Kashar } & $200,6 \%$ & & $120-800$ & \\
\hline & & & $53,88 \%$ & & 250 & \multirow{2}{*}{ [74] } \\
\hline & & White & $91,91 \%$ & & 250 & \\
\hline 62 & & Van otlu (Herb) & $60,86 \%$ & & $160-7260$ & \multirow{2}{*}[75]{} \\
\hline 63 & & White Pickle & $50,62 \%$ & & $100-5200$ & \\
\hline 64 & & Feta, Kashar liquid & $60 / 60$ & & 5 to 650 & [76] \\
\hline 65 & & White \& Kashar & $123 / 185$ & & 189.5 a 229.8 & [77] \\
\hline 66 & & Urfa & $4 / 64$ & & 51 to 100 & [78] \\
\hline 67 & & White \& Kashar & $28 / 40$ & & 40 to 388 & [79] \\
\hline 68 & & Kashar & $109 / 132$ & & 50 to 690 & [80] \\
\hline 69 & & Artisanal & $13 / 64$ & & $>250$ & [81] \\
\hline 70 & & Brined-Urfa & $36 / 127$ & & 70.6 a 770.9 & [82] \\
\hline 71 & & Ripened Konya küflü & $0 / 10$ & & 0 & [83] \\
\hline 72 & & Artisanal fresh cheese & $70 / 166$ & & 0.02 to 2.1 & [84] \\
\hline 73 & & Mouldy & $52 / 100$ & & 10.6 to 702 & [85] \\
\hline 74 & \multirow{5}{*}{ USA } & Swiss cheese & & \multirow{5}{*}{$M_{1}$} & & [86] \\
\hline 75 & & Parmesan \& Mozzarella & & & & [87] \\
\hline 76 & & Cheddar cheese & & & & [88] \\
\hline 77 & & Cottage cheese & & & & [89] \\
\hline 78 & & Cheese & $118,6 \%$ & & $100-1000$ & [90] \\
\hline
\end{tabular}

Table 1: Occurrence of Aflatoxins in cheeses worldwide.

Mexico, where raw milk had 0.005 to $0.100 \mu \mathrm{g} / \mathrm{L}$ and pasteurized milk had from 0.005 to $0.637 \mu \mathrm{g} / \mathrm{L}$, which is $18.6 \%(25 / 134)$ above the maximum tolerable level in the European Community [31].

There are studies on $\mathrm{AFM}_{1}$ in goat milk cheese in the State of Guanajuato, Mexico, which was found in $15 \%$ of the samples $(3 / 20)$, with a maximum amount of $0.23 \mu \mathrm{g} \mathrm{kg}^{-1}$. Goat milk exhibited $30 \%$ contamination, and $18 \%$ had a concentration $>0.05 \mu \mathrm{g} \mathrm{kg}^{-1}$ [32], which is the maximum tolerable level in the European Union.

A report of artisanal Oaxaca fresh cheese from the State of Veracruz, Mexico, examined $\mathrm{AFM}_{1}$ and $\mathrm{AFM}_{2}$ in 30 samples, with $16 / 30$ (53\%) having $\mathrm{AFM}_{1}$ contamination (0.01 to $\left.44 \mu \mathrm{g} \mathrm{kg}^{-1}\right)$. $\mathrm{AFM}_{2}$ was less frequent, present only in $6 / 30(20 \%)$, with a concentration range between 0.67 and $3.43 \mu \mathrm{g} \mathrm{kg}^{-1}$ [28].
The Mexican legislation on fresh, mature and industrialized cheese has no explicit maximum tolerance level for $\mathrm{AFM}_{1}$, although the milk used to make these cheeses must meet the sanitary criteria specified for pasteurized milk [32].

Of all the countries that reported $\mathrm{AFM}_{1}$ contamination in cheese, there were approximately $1,479(48.30 \%)$ positive for this mycotoxin. The most applied quantitative technique was ELISA with $60 \%$ frequency, followed by HPLC, with $38 \%$ frequency. AFM $_{1}$ was the most detected AF (92\%), and only three studies from Mexico reported more AFs in cheese (Table 1) [27,32].

The Middle East published 19 studies, with Turkey writing 8 manuscripts with 634 samples, of which 334 (52\%) showed AFM1. Meanwhile, the American continent has reported 9 studies related to 
Citation: Rojas-Marín V, Carvajal-Moreno M, González-Villaseñor MC, García-Hernández EA, González-Mendoza A (2018) Presence of Aflatoxin Carcinogens in Fresh and Mature Cheeses. Pharm Anal Acta 9: 581. doi: 10.4172/2153-2435.1000581

Page 4 of 6

the detection of AFs in cheeses, of which 3 are from Mexico and contain not only AFM 1 but also other AFs and hydroxylates that increase the ingestion and risk to humans. Very few studies have described AFB and $\mathrm{AFG}_{1}$ in cheese, and they were stable in Swiss cheese [91]. Only in Mexican reports were eight aflatoxins as well as hydroxylates, such as aflatoxicol (AFL) and aflatoxin $\mathrm{P}_{1}\left(\mathrm{AFP}_{1}\right)$, quantified in natural non-spiked cheese [27]. Other mycotoxins such as sterigmatocystin (STC), which is an aflatoxin precursor, have been detected in cheese [92]. Mycotoxin cheese contamination can occur indirectly via milk contamination or directly by mycotoxins producing spoilage or filamentous fungi [93].

The percentage of transference from cattle feed with $\mathrm{AFB}_{1}$ to elaborated dairy foods with $\mathrm{AFM}_{1}$ are as follows: cheese, 40 to $60 \%$; skim milk, 10\%; and butter, <2\% [94].

Several studies have detected $\mathrm{AFM}_{1}$ in cheese worldwide, and its presence is a public health concern. Several reviews of mycotoxins in cheese $[95,96]$ have enriched the knowledge about the subject. Iran and Turkey had the most numerous studies of $\mathrm{AFM}_{1}$ in cheese (Table 1).

The $\mathrm{AFM}_{1}$ stability in milk and dairy sub-products was reported [94], with no significant changes in the $\mathrm{AFM}_{1}$ concentration after pasteurization, boiling or ultra-pasteurization. There were no significant $\mathrm{AFM}_{1}$ concentration changes in cheese after 3 months of storage [97]. However, the binding ability of $\mathrm{AFM}_{1}$ by lactic acid bacteria such as Lactobacillus bulgaricus and Streptococcus thermophilus [98] effective in reducing the extent of free $\mathrm{AFM}_{1}$ content in liquid culture medium and during yogurt processing $[98,99]$. The stability of AFM during processing and storage makes it dangerous. As was expressed before, $\mathrm{AFM}_{1}$ from milk can be passed to cheese (Table 1).

For cheese-related Aspergillus spp., the AF biosynthetic pathway was reported to contain 25 genes clustered in a $70 \mathrm{~kb}$ region and involves at least 23 enzymatic reactions [100,101]. Aflatoxins are by far the most abundant and important mycotoxins in dairy product food and feed. Lethal dose (LD50) values range from 0.5 to $10 \mathrm{mg}$ $\mathrm{kg}^{-1}$ [102]. Aflatoxins are secondary metabolites that confer a selective advantage to the fungal producers within complex ecosystems, and they act as chemical signals to communicate; act as a competitive weapon to defend habitat by inhibiting the growth and reproduction of competitors of the same trophic niche competing with other organisms $[103,104]$; and play a role in survival functions [105].

\section{Conclusion}

$\mathrm{AFM}_{1}$ was the most reported contaminant of the AF hydroxylated metabolites, in cheese worldwide. ELISA and HPLC were the main techniques employed. There are few reports on other AFs in cheese, and in Mexico, eight different unreported AFs were published. Other $\mathrm{AFs}$, mainly $\mathrm{AFB}_{1}$ and $\mathrm{AFL}$ were found in artisanal and industrialized cheeses from Mexico because during processing, they incorporated maize flour that increases the AFs. The addition of all AFs (AFt) must be considered in cheeses because their amount of increase represents a higher risk for human health.

\section{Acknowledgments}

The authors express thanks to Posgrado en Ciencias Biomédicas, Universidad Nacional Autónoma de México [Posgraduate in Biomedical Sciences of the National Autonomous University of Mexico]

The authors thank the Instituto de Biología, Universidad Nacional Autónoma de México (IBUNAM), for the data of this work. The authors also thank IBUNAM's personnel: Noemí Chávez from the Secretaría Técnica, Joel Villavicencio, Jorge López, Alfredo Wong, Celina Bernal, Diana Martínez and Julio César Montero. Additionally, we thank Georgina Ortega Leite and Gerardo Arévalo for library information.

\section{References}

1. Fox PF (1993) Cheese: An Overview. In: Fox PF (eds) Cheese: Chemistry, Physics and Microbiology. Springer 1-36.

2. Dohlman E (2003) Mycotoxin Hazards and Regulations: Impacts on Food and Animal Feed Crop Trade. Chapter 6; In: International Trade and Food Safety: Economic Theory and Case Studies Jean C. Buzby, ed. Agricultural Economic Report No. 828, Electronic Report from the Economic Research Service USDA USA pp: $97-108$

3. Gante AV, Escoto FC, Vargas AC, Ortega AE, Montes AH, et al. (2015) Atlas de los Quesos Mexicanos Genuinos. Agricultura Sociedad y Desarrollo 12 257-260.

4. Cesín-Vargas A (2014) La leche y los quesos artesanales en México. Agricultura Sociedad y Desarrollo 11: 243-248.

5. Cogan TM (2011) Microbiology of cheese. In: Fuquay JW (2 ${ }^{\text {nd }}$ Edn) Encyclopedia of dairy sciences, San Diego: academic press, pp: 625-631.

6. Carr FJ, Chill D, Maida N (2002) The lactic acid bacteria: A literature survey Crit Rev Microbiol 28: 281-370.

7. Ropars J, López-Villavicencio M, Snirc A, Lacoste S, Giraud T (2017) Blue cheese-making has shaped the population genetic structure of the mould Penicillium roqueforti. PLoS ONE 12: 103.

8. Montero E (2013) Situación actual y perspectivas del sector lácteo a nive mundial. Congreso Nacional Lechero. Cámara Nacional de Productores de Leche. Costa Rica.

9. http://www.fao.org/docrep/007/y5499e/y5499e07.htm

10. Fallah AA, Jafari T, Fallah A, Rahnama M (2009) Determination of aflatoxin $M$ levels in Iranian white and cream cheese. Food Chem Toxicol 47: 1872-1875.

11. Wogan GN, Edwards GS, Newberne PM (1971) Structure activity relationships in toxicity and carcinogenicity of aflatoxins and analogs. Cancer Res 31: 19361942

12. Hussein HS, Brasel JM (2001) Toxicity, metabolism, and impact of mycotoxins on humans and animals. Toxicology 167: 101-134.

13. Carvajal M (2013) Transformación de la aflatoxina $B_{1}$ de alimentos, en el cancerígeno humano, aducto $\mathrm{AFB}_{1}-\mathrm{ADN}$. TIP Revista especializada en Ciencias Químico-Biológicas 16: 109-120.

14. https://monographs.iarc.fr/ENG/Monographs/vol82/mono82.pdf

15. IARC, International Agency for Research on Cancer (1997) Naturally occurring aflatoxins (Group 1), aflatoxin M1 (Group 2B) 08/21/1997. Monographs on the evaluation of carcinogenic risks to humans. Some naturally occurring substances: Food items and constituents, heterocyclic aromatic amines and mycotoxins 56, 5.1-5.5, Lyon France.

16. Carvajal M, Berumen J, Guardado-Estrada M (2012) The presence of AFB FAPY adduct and human papilloma virus in cervical smears from cance patients in Mexico. Food Addit Contam Part A Chem Anal Control Expo Risk Assess 29: 258-268.

17. Harrison JC, Carvajal M, Garner RC (1993) Does aflatoxin exposure in the United Kingdom constitute a cancer risk? Environ Health Perspect 99: 99-105.

18. Shephards GS (2003) Aflatoxin and food safety: Recent African Perspectives J Toxicol Toxin Rev 22: 267-286.

19. Kensler TW, Roebuck BD, Wogan GN, Groopman JD (2011) Aflatoxin: A 50year Odyssey of Mechanistic and Translational Toxicology. Toxicol Sci 120: $28-48$.

20. Anfossi L, Baggiani C, Giovannoli C, D'Arco G, Passini C, et al. (2012) Occurrence of aflatoxin $M_{1}$ in Italian cheese: Results of a survey conducted in 2010 and correlation with manufacturing, production season, milking animals, and maturation of cheese. Food Control 25: 125-130.

21. Creppy EE (2002) Update of survey, regulation and toxic effects of mycotoxins in Europe. Toxicol Lett 127: 19-28.

22. Garrido NS, Iha MH, Santos Ortolani MR, Duarte Fávaro RM (2003) Occurrence of aflatoxins $M_{1}$ and $M_{2}$ in milk commercialized in Ribeirão Preto-SP, Brazil. Food Addit Contam 20: 70-73.

23. Kos J, Lević J, Đuragić O, Kokić B, Miladinović I (2014) Occurrence and estimation of aflatoxin $M_{1}$ exposure in milk in Serbia. Food Control 38: 41-46. 
Citation: Rojas-Marín V, Carvajal-Moreno M, González-Villaseñor MC, García-Hernández EA, González-Mendoza A (2018) Presence of Aflatoxin Carcinogens in Fresh and Mature Cheeses. Pharm Anal Acta 9: 581. doi: 10.4172/2153-2435.1000581

Page 5 of 6

24. Weidenborner $M$ (2011) Mycotoxins and their metabolites in human and animals. Springer Science, Business Media, LLC

25. Carvajal M, Rojo F, Méndez I, Bolaños A (2003) Aflatoxin $B_{1}$ and its interconverting metabolite aflatoxicol in milk: the situation in Mexico. Food Addit Contam 20: 1077-1086.

26. Carvajal M, Bolaños A, Rojo F, Méndez I (2003) Aflatoxin M in pasteurized and ultrapasteurizedmilk with different fat content in Mexico. J Food Protect 66: $1885-1892$

27. Ortiz MV, Moreno MC, Camarillo EH, Velasco SR, Callejas FR (2017) Unreported aflatoxins and hydroxylate metabolites in artisanal Oaxaca cheese from Veracruz, Mexico. Biochem Anal Biochem 6: 322

28. Camarillo EH, Moreno MC, Olvera VJR, Ortiz MAV, Cervantes MAS (2016) Quantifying the levels of the mutagenic, carcinogenic hydroxylated aflatoxins $\left(A F M_{1}\right.$ and $\left.A F M_{2}\right)$ in artisanal Oaxaca-Type cheeses from the City of Veracruz, Mexico. J Microb Biochem Technol 8: 491-497.

29. Izquierdo AC, Oaxaca JS, Lang GR, Suárez SC, Campos VMX, et al. (2007) Identification of $M_{1}$ aflatoxin in milk of the collector tank. J Anim Vet Adv 6: 194-197.

30. Pérez J, Gutiérrez R, Vega S, Díaz G, Urbán G, et al. (2008) Ocurrencia de aflatoxina $M$ en leches cruda, ultrapasteurizadas y orgánica en el Altiplano Mexicano. Rev Salud Anim Habana Cuba 30: 103-109.

31. Landeros P, Noa M, López Y, González DG, Noa E, et al. (2012) Niveles de aflatoxina $M$ en leche cruda y pasteurizada comercializada en la zona metropolitana de Guadalajara, Mexico. Rev Salud Anim 34: 40-45.

32. Urbán G, Pérez J, Martínez F, Salas J, Díaz G, et al. (2009) Niveles de aflatoxina $M_{1}$ en quesos frescos producidos en diferentes zonas de México. Revista de Salud Animal 31: 115-121.

33. Taniwaki MH, Van Dender AGF (1992) Occurrence of toxigenic molds in Brazilian cheese. J Food Prot 55: 187-191.

34. Iha MH, Barbosa CB, Okada IA, Trucksess MW (2011) Occurrence of aflatoxin $\mathrm{M}_{1}$ in dairy products in Brazil. Food Control 22: 1971-1974.

35. Oliveira CAF, Franco RC, Rosim RE, Fernandes AM (2011) Survey of aflatoxin $M_{1}$ in cheese from the North-east region of São Paulo, Brazil. J Food Addit Contam Part B Surveillance 4: 57-60.

36. Iha MH, Barbosa CB, Okada IA, Trucksess MW (2013) Aflatoxin M1 in milk and distribution and stability of aflatoxin M1 during production and storage of yoghurt and cheese. Food Control 29: 1-6.

37. Trombete FM, Castro IM, Teixeira AS, Saldanha T, Fraga ME (2014) Aflatoxin M1contamination in grated parmesan cheese marketed in Rio de Janeiro Brazil. Braz Arch Biol Technol 57: 269-273.

38. Brezina P, Mrazek J, Lohnisky J (1983) Occurrence of aflatoxin in Edam-type cheeses. Prumysl Potravin 34: 413-415.

39. ShiChun P, YuanYuan Z, Eremin SA, WonJong L (2009) Detection of aflatoxin $\mathrm{M}_{1}$ in milk products from China by ELISA using monoclonal antibodies. Food Control 20: 1080-1085

40. http://www.javeriana.edu.co/biblos/tesis/ciencias/tesis350.pdf

41. Chavarría G, Chinchilla FG, Cascante MA, Molina A (2015) Detection of aflatoxin M1 in milk, cheese and sour cream samples from Costa Rica using enzyme-assisted extraction and HPLC. Food Addit Contam B Surveillance 8: 128-135.

42. Kokkonen M, Jestoi M, Rizzo A (2005) Determination of selected mycotoxins in mould cheeses with liquid chromatography coupled to tandem with mass spectrometry. Food Addit Contam 22: 449-456.

43. http://repositorio.upn.edu.pe/handle/11537/9925

44. Awad El, Amer IH, Mansour H, Ismail SEY (2014) Qualitative and quantitative detection of Aflatoxin $M_{1}$ residues in white soft cheese. Alexandria $\mathrm{J}$ Vet Sci 40: $119-123$.

45. Karaioannoglou PG, Mantia A, Koufidia D, Koidia P, Triantafillou J (1989) Occurence of aflatoxin $M_{1}$ in raw and pasteurized milk and in Feta and Teleme cheese samples. Milchwissenschaft 44: 746-748.

46. http://ijph.tums.ac.ir/index.php/ijph/article/view/2818/2798

47. Shahbazi Y, Zahra N, Negin K (2017) Occurrence, seasonal variation and risk assessment of exposure to aflatoxin $\mathrm{M}_{1}$ in Iranian traditional cheeses. Food Control 79: 356-362.
48. Sharifzadeh A, Dehkordi PG, Foroughi M, Shahrekordi EM, Ramazi S (2017) Aflatoxin $M_{1}$ contamination levels in cheeses sold in Isfahan Province, Iran. Osong Public Health Res Perspect 8: 260-263.

49. Bahrami R, Shahbazi Y, Nikousefat Z (2016) Aflatoxin M1 in milk and traditiona dairy products from west part of Iran: Occurrence and seasonal variation with an emphasis on risk assessment of human exposure. Food Control 62: 250256.

50. Rezaei M, Fani A, Moini AL, Mirzajani P, Malekirad AA, et al. (2015) Assessmen of aflatoxin $M$, levels in pasteurised milk, raw milk, and cheese in Arak, Iran. Toxin Rev 34: 61-65.

51. Rahimirad A, Malekinejad H, Ostadi A, Yeganeh S, Fahimi S (2014) Aflatoxin M1 concentration in various dairy products: evidence for biologically reduced amount of AFM1 in yoghurt. Iranian J Public Health 43: 1139-1144.

52. Castelli S, Riberzani A (1981) Aflatossina $M_{1}$ nel latte e derivate. Aspetti igienico-sanitari e problemi analitici. Att Soc Italian Sci Vet 35: 671-672.

53. Finoli C, Vecchio A, Bellavita M, Cerruti G (1983) Sulla presenza di aflatossina $M_{1}$ in latte e derivati. Latte 8: 611-625

54. Montagna MT, Napoli C, De Giglio O, latta R, Barbuti G (2008) Occurrence of Aflatoxin $M_{1}$ in dairy products in southern Italy. Int J Mol Sci 9: 2614-2621.

55. Santini A, Raiola A, Ferrantelli V, Giangrosso G, Macaluso A, et al. (2013) Aflatoxin $M_{1}$ in raw, UHT milk and dairy products in Sicily (Italy). Food Addit Contam B Surveillance 6: 181-186.

56. Cavallarin L, Antoniazzi S, Giaccone D, Tabacco E, Borreani G (2014) Transfe of aflatoxin $\mathrm{M}$ from milk to ripened cheese in three Italian traditional production methods. Food Control 38: 174-177.

57. Tabata S, Kamimuro H, Tamura Y, Yasuda K, Oshiyama H, et al. (1987) Aflatoxin contamination in foods and foodstuff. J Food Hygiene Soc Japan 28: 395-401.

58. Taguchi S, Fukushima S, Sumimoto T, Yoshida S, Nishimune T (1995) Aflatoxins in food collected in Osaka Japan from 1988 to 1992. J AOAC Int 78: $325-327$.

59. Yoon BR, Hong SY, Cho SM, Lee KR, Kim MH, et al. (2016) Aflatoxin M, levels in dairy products from South Korea determined by high performance liquid chromatography with fluorescence detection. J Food Nutr Res 55: 171-180.

60. Dashti B, Al-Hamli S, Alomirah H, Al-Zenki S, Abbas AB, et al. (2009) Levels of aflatoxin $M_{1}$ in milk cheese consumed in Kuwait and occurrence of total aflatoxin in local and imported animal feed. Food Control 20: 686-690.

61. Urbán G, Pérez J, Martínez F, Gutiérrez R, Vega S, et al. (2010) Aflatoxina $M_{1}$ en leche y queso de cabra producidos en Apaseo El Grande Guanajuato, México. Rev Salud Anim La Habana, Cuba 32: 84-88.

62. Sprong RC, De Wit-Bos L, Te Biesebeek JDM, Alewijin M, Lopez P, et al (2013) A mycotoxin-dedicated total diet study in the Netherlands in 2013 Exposure and risk assessment. World Mycotoxin J 9: 109-128.

63. Elgerbi AM, Aidoo KE, Candlish AAG, Tester RF (2004) Occurence of aflatoxin $M_{1}$ in randomly selected North African milk and cheese samples. Food Addit Contam 21: 592-597.

64. Martins HM, Magalhães AS, Almeida I, Marques M, Guerra MM, et al. (2007) Aflatoxin $M_{1}$ determination in cheese by immunoaffinity column cleanup coupled to high-performance liquid chromatography. Rev Port Ciênc Vet 102: 321-325.

65. Valasutean G, Tăbăran A, Reget O, Dan SD, Mihaiu M (2015) Evaluation of aflatoxin M1 incidence in raw milk and ripened cheese retailed in a traditional market. Lucrari Stiintifice Universitatea de Stiinte Agricole a Banatului Timisoara, Medicina Veterinara 48: 245-249.

66. Barrios MJ, Gualda MJ Cabanas MJ, Medina LM, Jordano R (1996) Occurrence of Aflatoxin $M_{1}$ in cheeses from the South of Spain. J Food Prot 59: 898-900.

67. López-Díaz TM, Román-Blanco C, García-Arias MT, García Fernández MC García-López ML (1996) Mycotoxins in two Spanish cheese varieties. Int Food Microbiol 30: 391-395.

68. Cano-Sancho G, Marin S, Ramos A, Peris-Vicente J, Sanchis V (2010) Occurrence of aflatoxin $M$ and exposure assessment in Catalonia (Spain). Rev Iberoam Micol 27: 130-135.

69. Rubio R, Moya VJ, Berruga MI, Molina MP, Molina A (2011) Aflatoxin $M_{1}$ in the intermediate dairy products from Manchego cheese production: distribution and stability. Mljekarstvo 61: 283-290. 
Citation: Rojas-Marín V, Carvajal-Moreno M, González-Villaseñor MC, García-Hernández EA, González-Mendoza A (2018) Presence of Aflatoxin Carcinogens in Fresh and Mature Cheeses. Pharm Anal Acta 9: 581. doi: 10.4172/2153-2435.1000581

70. Torkar KG, Vengušt A (2008) The presence of yeasts, moulds and aflatoxin M1 in raw milk and cheese in Slovenia. Food Control 19: 570-577.

71. Gürses M, Erdogan A, Çetin B (2004) Occurence of aflatoxin M1 in some cheese types sold in Erzurum, Turkey. Turk J Vet Anim Sci 28: 527-530.

72. Sarımehmetoglu B, Kuplulu O, Celik TH (2004) Detection of aflatoxin $M_{1}$ in cheese samples by ELISA. Food Control 15: 45-49.

73. Yaroglu T, Oruc HH, Tayar M (2005) Aflatoxin $M_{1}$ levels in cheese samples from some provinces of Turkey. Food Control 16: 883-885.

74. Aycicek H, Aksoy A, Saygi S (2005) Determination of aflatoxin levels in some dairy and food products which consumed in Ankara, Turkey. Food Control 16: 263-266.

75. Tekinşen KK, Tekinşen OC (2005) Aflatoxin $M_{1}$ in white pickle and Van otlu (herb) cheeses consumed in southeastern Turkey. Food Control 16: 565-568.

76. Kireçci E, Savașçı M, Ayyıldız A (2007) Detection of aflatoxin M1 in milk and cheese products consumed in Sarikamiș, Turkey. Turkish J Infection 21: 93-96.

77. Dinçoğlu $A H$, Gönülalan Z, Kök F (2007) Determination of aflatoxin $M_{1}$ levels in cheese sold in Izmit province. LucrariStiintifice-Universitatea de Stiinte Agricole a Banatului Timisoara, Medicina Veterinara 40: 758-763.

78. Ardic M, Atasever M, Adiguzel G, Atasever M, Karakaya Y, et al. (2008) Survey on the presence of aflatoxin M1 in urfa cheese. Int J Food Safety 10: 92-96.

79. Var I, Kabak B (2009) Detection of aflatoxin M1 in milk and dairy products consumed in Adana, Turkey. Int J Dairy Technol 62: 15-18.

80. Tekinşen KK, Eken SH (2008) Aflatoxin $M_{1}$ levels in UHT milk and kashar cheese consumed in Turkey. Food Chem Toxicol 46: 3287-3289.

81. Gücükoğlu A, Çadırcı Ö, Özpınar N (2010) Detection of aflatoxin $M_{1}$ in UHT milk and cheese samples. Etlik Veteriner Mikrobiyoloji Dergisi 21: 45-50.

82. Kav K, Col R, Tekinsen K (2011) Detection of aflatoxin $M_{1}$ levels by ELISA in white-brined Urfa cheese consumed in Turkey. Food Control 22: 1883-1886.

83. Güley Z, Uysal HR, Kılıç S (2013) Investigation of the presence of aflatoxin $M_{1}$, aflatoxin $B_{1}$ and aflatoxigenic moulds in some naturally mould-ripened traditional cheeses. Ege Üniversitesi Ziraat Fakültesi Dergisi 50: 145-152.

84. Bakırdere S, Yaroğlu T, Tırık N, Demilröz M, Karaca A (2014) Determination of trace aflatoxin M1 levels in milk and milk products consumed in Turkey by using enzyme-linked immunosorbent assay. Food Agric Immunol 25: 61-69.

85. Özgören E, Seçkin AK (2016) Aflatoxin $M_{1}$ contaminations in mouldy cheese. Mljekarstvo 66: 154-159.

86. Bullerman LB (1976) Examination of Swiss cheese for incidence of mycotoxin producing molds. J Food Sci 41: 26-28.

87. Brackett RE, Marth EH (1982) Fate of aflatoxin $m_{1}$ in parmesan and mozzarella cheese. J Food Prot 45: 597-600.

88. Brackett RE, Marth EH (1982) Fate of aflatoxin $m_{1}$ in cheddar cheese and in process cheese spread. J Food Prot 45: 549-552.
89. Applebaum RS, Marth EH (1982) Fate of aflatoxin $m_{1}$ in cottage cheese. J Food Prot 45: 903-904.

90. Trucksess MV, Page SV (1986) Examination of imported cheese for aflatoxin M1. J Food Prot 49: 632-633.

91. Lieu FY, Bullerman LB (1977) Production and stability of aflatoxins, penicillic acid and patulin in several substrates. J Food Sci 42: 1222-1224.

92. Northold MD, Van Egmond HP, Soentoro R, Deijll E (1980) Fungal growth and the presence of sterogmatocistin in hard cheese. J Assoc Off Anal Chem 63 115-119.

93. O'Brien NM, O'Connor TP, O'Callaghan J, Dobson ADW (2004) Toxins in cheese. in: cheese: chemistry, physics and microbiology. Elsevier Applied Science, Amsterdam.

94. Yousef AE, Marth EH (1989) Stability and degradation of Aflatoxin $M_{1}$. In mycotoxins in dairy products. Elsevier, USA.

95. Mulunda M, Ngoma L, Nyirenda M, Motsei L, Bakunzi F (2013) A decade of aflatoxin $\mathrm{m} 1$ surveillance in milk and dairy products in developing countries (2001-2011): A Review. In: Mycotoxin and Food Safety in Developing Countries.

96. Sengun IY, Yaman DB, Gonul SA (2008) Mycotoxins and mould contamination in cheese: a review. World Mycotoxin J 1: 291- 298.

97. Deveci $O$ (2006) Changes in the concentration of aflatoxin $M_{1}$ during manufacture and storage of White Pickled cheese. Food Control 18: 1103 1107

98. Khoury A El, Atoui A, Yaghi $\mathrm{J}$ (2011) Analysis of aflatoxin $\mathrm{M}_{1}$ in milk and yogurt and $A F M_{1}$ reduction by lactic acid bacteria used in Lebanese industry. Food Control 22: 1695-1699.

99. Darsanaki RZ, Marjan M (2013) Aflatoxin $M_{1}$ contamination in dairy products. $J$ Sci and today's world 2013 2: 500-514.

100. Yu JJ, Chang PK, Ehrlich KC, Cary JW, Bhatnagar D, et al. (2004) Clustered pathway genes in aflatoxin biosynthesis. Appl Environ Microbiol 70: 12531262.

101. Huffman J, Gerber R, Liangcheng D (2010) Recent advancements in the biosynthetic mechanisms for polyketide-derived mycotoxins. Biopolymers 93 764-776.

102. Hymery N, Vasseur V, Coton M, Mounier J, Jany J-L, et al. (2014) Filamentous fungi and Mycotoxins in cheese : A Review. Comprehensive Rev in Food Sci and Food Safety 13: 437-456.

103. Magan N, Aldred D (2007) Why do fungi produce mycotoxins? In: Food Mycology: a multifaceted approach to fungi and food. Taylor and Francis Group, USA.

104. Fox EM, Howlett $B(2008)$ Secondary metabolism: regulation and role in fungal biology. Curr Opin Microbiol 11: 481-487.

105. Demain AL, Fang A (2000) The natural functions of secondary metabolites. Adv Biochem Eng Biotechnol 69: 1-39. 